\title{
Comparison of Cultural and Immunofluorescent Procedures in the Identification of Haemophilus vaginalis
}

\author{
By DONNA L. REDMOND AND E. KOTCHER \\ University of Louisville, School of Medicine, Louisville 2, Kentucky, U.S.A.
}

(Received 22 March 1963)

\begin{abstract}
SUMMARY
The application of immunofluorescent techniques for the detection and identification of Haemophilus vaginalis in vaginal secretions by using fluorescent $\boldsymbol{H}$. vaginalis antiglobulin (strains nos. 317, 4984) were found to be as specific and sensitive as cultural methods and had the advantage of being simple and rapid.
\end{abstract}

\section{INTRODUCTION}

Several investigators (Leopold, 1953; Gardner \& Dukes, 1954, 1955; Gardner, Dampeer \& Dukes, 1957; Amies \& Jones, 1957; Brewer, Halpern \& Thomas, 1957; Edmunds, 1960; Lapage, 1961) have reported the occurrence of a small, Gramnegative bacillus in the male and female genitro-urinary tract. These investigators used various media for the isolation and cultivation of this organism, named Haemophilus vaginalis by Gardner \& Dukes (1955). Although most of the investigators used the criteria for identification established by Gardner \& Dukes, several of the reports varied as to the cultural behaviour and staining characteristics. The organism was regarded as quite fastidious. In view of these problems, it was decided to compare immunofluorescent procedures, which had been found to be highly specific (Redmond \& Kotcher, 1963) with cultural procedures, Gramstained smears, and 'clue-cells' in the isolation and identification of this organism from clinical material at Houston, Texas and Louisville, Kentucky, U.S.A.

\section{METHODS}

Media. In the cultural procedures used in Louisville the following media were employed for the isolation of organisms from vaginal swabs which had been put into proteose peptone no. 3 (Difco) carrying broth; Casman agar with $5 \%$ sterile, defibrinated rabbit blood; Rogosa agar; blood agar (human out-dated blood); eosin-methylene blue agar; GC medium (Difco); PPLO broth and agar (Difco); National Institutes of Health thioglycollate with and without $5 \%$ horse serum; and Douglas broth.

In the cultural procedures used at Houston, Brewer thioglycollate broth without methylene-blue indicator (Baltimore Biological Laboratories) was used as the transport medium for clinical specimens. Casman rabbit blood agar was used for isolation. Any organism that could not be identified from this primary culture was subcultured on special media for identification. In both laboratories (Louisville, Houston) the Casman plates were cultured in a candle jar at $37^{\circ}$. The vaginal swabs in transport medium were streaked on cultivation media within 2-6 hr. after having 
been obtained from the patient. The criteria for the identification of Haemophilus vaginalis were those given by Dukes \& Gardner (1961).

Staining methods. The staining methods, immunization of rabbits, the method of conjugating fluorescein isothlocyanate to the globulin from the antiserum of immunized rabbits, and the immunofluorescent procedures were as described by Redmond \& Kotcher (1963).

Clinical methods. Each patient was examined for symptoms of vulvitis, vaginitis and cervicitis by a gynaecologist. Vaginal secretion smears were made on three microscope slides and a vaginal swab was inoculated into a transport medium. A drop of vaginal secretion was examined by wet-mount for the presence of 'clue cells', leucocytes, Trichomonas vaginalis, and yeast-like organisms. One vaginal smear was Gram-stained and examined for the presence of small Gram-negative bacilli and 'clue cells'. A second vaginal smear was fixed in absolute methanol for 5 min., air dried, and stained with fluorescent Haemophilus vaginalis antiglobulin by the direct method. This smear was examined for fluorescent bacteria. The third vaginal smear was fixed in absolute methanol and held in reserve.

Table 1. Comparison of four methods in studying Haemophilus vaginalis in three groups of patients

\begin{tabular}{|c|c|c|c|c|c|c|}
\hline \multicolumn{7}{|c|}{ Number of patients and group } \\
\hline \multirow{2}{*}{$\begin{array}{c}27 \text { private } \\
\text { patients } \\
\text { (Houston, } \\
\text { Texas) }\end{array}$} & \multirow{2}{*}{$\begin{array}{c}\text { 54 private } \\
\text { patients } \\
\text { (Louisville, } \\
\text { Kentucky) }\end{array}$} & \multirow{2}{*}{$\begin{array}{l}\text { 51 clinic } \\
\text { patients } \\
\text { (Louisville, } \\
\text { Kentucky) }\end{array}$} & \multicolumn{4}{|c|}{ Method } \\
\hline & & & Culture & $\begin{array}{l}\text { Fluorescent } \\
\text { antibody }\end{array}$ & $\begin{array}{l}\text { Clue } \\
\text { cell* }\end{array}$ & $\begin{array}{c}\text { Gram } \\
\text { stains }\end{array}$ \\
\hline 14 & $\mathbf{3}$ & 5 & + & + & + & + \\
\hline 0 & $\mathbf{0}$ & $\mathbf{0}$ & + & + & + & - \\
\hline $\mathbf{0}$ & $\mathbf{0}$ & 0 & + & + & - & - \\
\hline $\mathbf{0}$ & 0 & $\mathbf{0}$ & + & - & - & - \\
\hline 3 & 3 & 1 & - & - & - & - \\
\hline $\mathbf{0}$ & 1 & 1 & - & + & + & + \\
\hline $\mathbf{0}$ & 1 & 2 & - & - & + & + \\
\hline 5 & 36 & 38 & - & - & - & + \\
\hline 0 & 0 & 0 & + & - & + & + \\
\hline 4 & 5 & 3 & + & + & - & + \\
\hline 0 & 0 & 0 & - & + & + & - \\
\hline 0 & 0 & 0 & - & + & - & - \\
\hline 0 & 1 & 0 & - & - & + & - \\
\hline 0 & 0 & 1 & + & - & - & + \\
\hline 1 & 4 & $\mathbf{0}$ & - & + & - & + \\
\hline 0 & 0 & 0 & + & - & + & - \\
\hline
\end{tabular}

* Clinic patients were examined for clue cells by Gram-stained smears rather than by wet mount.

\section{RESULTS}

A comparison of four methods for studying Haemophilus vaginalis, namely, culture, FA staining, presence of 'clue cells', and Gram reaction is presented in Table 1. FA staining revealed the presence of $H$. vaginalis in five patients from whom the organism was not cultured. In no instance was the organism cultured and not found on vaginal smears by FA staining. The 'clue cell' and the Gram-reaction observations are incorporated in Table 1 although it is realized that these techniques are not specific for $H$. vaginalis. 
The incidence of Haemophilus vaginalis, as revealed by FA staining, accepted cultural procedures and by both methods in the same three groups of patients is presented in Table 2. The Houston patients were highly selected because it was decided to use such a group as a control to determine the sensitivity and specificity of the methods. No such selection was carried out with either group at Louisville.

Table 2. Incidence of Haemophilus vaginalis by fluorescent antibody and cultural methods

\begin{tabular}{|c|c|c|c|c|c|c|}
\hline \multirow[b]{2}{*}{ Number of patients and group } & \multicolumn{2}{|c|}{$\begin{array}{l}\text { Positive } \\
\text { culture }\end{array}$} & \multicolumn{2}{|c|}{$\begin{array}{l}\text { Positive } \\
\text { fluorescent } \\
\text { antibody }\end{array}$} & \multicolumn{2}{|c|}{$\begin{array}{c}\text { Positive } \\
\text { culture } \\
\text { and } \\
\text { fluorescent } \\
\text { antibody }\end{array}$} \\
\hline & No. & $\%$ & No. & $\%$ & No. & $\%$ \\
\hline 27 private patients, Houston, Texas & 19 & 70 & 19 & 70 & 19 & 70 \\
\hline 54 private patients, Louisville, Kentucky & 8 & $\mathbf{1 5}$ & 13 & $\mathbf{2 4}$ & 8 & 15 \\
\hline 51 clinic patients, Louisville, Kentucky & 9 & 18 & 9 & 18 & 8 & $\mathbf{1 6}$ \\
\hline
\end{tabular}

A great variety of organisms may be found in the vagina, particularly in patients with vaginitis, cervicitis and vulvitis. In Table 3 a list is given of other organisms found in association with Haemophilus vaginalis in the three groups of patients examined. There was a considerable difference in the frequency with which certain organisms, such as Staphylococcus aureus, Streptococcus viridans, Micrococcus sp., Escherichia coli, diphtheroids, and Doederlein's bacillus were isolated as between the Houston patients and the Louisville patients. However, different cultural procedures were used and different bacteriologists were involved in studying the patients of the two cities.

Table 3. Other organisms found in association with Haemophilus vaginalis in vaginal secretions

\begin{tabular}{|c|c|c|c|}
\hline \multirow[b]{2}{*}{$\begin{array}{l}\text { Organisms associated with } \\
\text { Haemophilus vaginalis }\end{array}$} & \multicolumn{3}{|c|}{ Number of patients and group } \\
\hline & $\begin{array}{c}19 \text { private } \\
\text { patients } \\
\text { (Houston, } \\
\text { Texas) }\end{array}$ & $\begin{array}{c}13 \text { private } \\
\text { patients } \\
\text { (Louisville, } \\
\text { Kentucky) }\end{array}$ & $\begin{array}{r}10 \text { clinic } \\
\text { patients } \\
\text { (Louisville, } \\
\text { Kentucky) }\end{array}$ \\
\hline Trichomonas vaginalis & $\mathbf{3}$ & 2 & $\mathbf{3}$ \\
\hline Candida sp. & 1 & $\overline{1}$ & $\mathbf{0}$ \\
\hline Staphylococcus aureus & $\mathbf{1}$ & 5 & $\mathbf{5}$ \\
\hline Streptococcus viridans & 8 & 1 & 0 \\
\hline S. anhemolyticus & 0 & $\mathbf{1}$ & 0 \\
\hline S. hemolyticus & 0 & 2 & $\mathbf{0}$ \\
\hline Enterococcus & $\mathbf{0}$ & 2 & 0 \\
\hline Sarcina sp. & 0 & $\overline{3}$ & 1 \\
\hline Micrococcus sp. & 6 & 0 & $\mathbf{0}$ \\
\hline Escherichia coli & $\mathbf{0}$ & $\mathbf{3}$ & 1 \\
\hline Diphtheroids & 16 & 1 & 4 \\
\hline Doederlein's bacillus & $\mathbf{0}$ & 10 & 4 \\
\hline No organism & $\mathbf{1}$ & 0 & 2 \\
\hline
\end{tabular}

The complete flora studies on the Louisville, Kentucky, groups were done by Miss Carolyn Frick. The flora studies on the Houston, Texas group were done by Mrs Martha Foster. 


\section{DISCUSSION}

In interpreting the results of the three patients groups, the Houston group was considered as the control group. The clinician selected the patients by clinical signs and symptoms of Haemophilus vaginalis vaginitis, and also included normal women, and women with vaginitis caused by organisms other than $H$. vaginalis in this group. The two groups of patients from Louisville were randomly selected patients; however, some patients from the private practice group were suspected by clinical observation of having $H$. vaginalis vaginitis.

The fluorescent Haemophilus vaginalis antiglobulin was as sensitive as cultural techniques in identifying $\boldsymbol{H}$. vaginalis. In the clinical specimens examined, FA methods revealed six additional specimens (five patients) with $H$. vaginalis which was not isolated by cultural methods. Non-specific fluorescence was ruled out by subjecting the other species of bacteria isolated to staining with fluorescent $H$. vaginalis antiglobulin by the direct immunofluorescent method. In a single case from the Louisville gynaecology clinic, $H$. vaginalis was isolated by cultural methods, whereas the vaginal smear from this patient was negative by direct immunofluorescent reaction. However, the culture of $H$. vaginalis was positive for fluorescence by the direct immunofluorescent reaction.

Because of the fastidious nature of Haemophilus vaginalis, it is necessary to use a highly enriched culture medium, such as Casman rabbit blood agar, for the isolation of the organism. On this medium other organisms from the vagina grow rapidly and may, on occasion, overgrow $\boldsymbol{H}$. vaginalis. In cultivating this fastidious bacillus from clinical specimens it is important that the specimens do not remain in transport media more than 6-8 hr. or the organisms will not survive. Because of these cultural and transport difficulties, it is believed that FA techniques are more practical in the identification of $\boldsymbol{H}$. vaginalis particularly as in this investigation the use of fluorescent $H$. vaginalis antiglobulin was as specific and somewhat more sensitive than culture methods. Also, it has the advantage of simplicity and rapidity, as well as not requiring the processing of the clinical specimen immediately, which is necessary with cultural procedures.

The difference in the percentage incidence of Haemophilus vaginalis in the Houston patients as compared with the Louisville patients is explained by the fact that the Houston gynaecologist selected his patients for $H$. vaginalis vaginitis. The two Louisville groups were unselected, and the incidence in this series of patients was comparable to that found by Gardner et al. (1957), Ritzerfeld \& Kummel (1960), Kummel \& Ritzerfeld (1961), and Wurch \& Lutz (1955). The incidence of $\boldsymbol{H}$. vaginalis in Louisville, however, was lower than that reported by Brewer et al. (1957), Edmunds (1959) and De La Fuente, Rico \& Soria (1959).

Although Gardner \& Dukes (1955) recommended the wet mount for the detection of 'clue cells', other investigators (Edmunds, 1959; Lapage, 1961) have also used the Gram-stained vaginal smear. In the present work, patients from the Louisville clinic group were examined for 'clue cells' by Gram-stained smears. Small Grampositive organisms were frequently found attached to the epithelial cells, thus producing the same phenomenon in wet mounts as when Haemophilus vaginalis was attached to the cells. In the two Louisville groups, 'clue cells' were present when cultural and immunofluorescent methods did not reveal $H$. vaginalis (Table $\mathbf{1}$ ); 
it was also noted that $H$. vaginalis was found when 'clue cells' were absent. LaPage (1961) observed Gram-positive and Gram-negative mixed 'clue cells', thus casting doubt on the significance of the association of such cells with the isolation of the small Gram-negative bacillus.

Comparison of the organisms found in association with Haemophilus vaginalis in the vaginal secretions of the three groups studied showed a marked difference as between the Houston group and the two Louisville groups (Table 3). The flora studies of the three groups were not made with identical transport and cultural media, nor were the bacteriologists the same. These technical differences are probably the most satisfactory explanation for the differences observed in the vaginal floras. The absence of Doederleins' bacillus from the Houston group and its presence in the two Louisville groups is the most striking feature. However, Rogosa medium or tomato juice agar medium was not used in studying the Houston group, and for this reason Doederlein's bacillus may have been missed.

In comparing the two Louisville groups, Doederlein's bacillus and Staphylococcus aureus were the organisms most frequently associated with Haemophilus vaginalis. Trichomonas vaginalis was associated with $H$. vaginalis in $18 \%$ of the Louisville private practice group, $28 \%$ of the Louisville clinic group, and $16 \%$ of the Houston private practice group. Diphtheroids were frequently isolated from the Louisville clinic group and the Houston private practice group; however, they are considered to be part of the normal vaginal flora. Brewer et al. (1957), Heltai (1959), Edmunds (1959), and LaPage (1961) stated that $H$. vaginalis was isolated more frequently with a mixed microbial flora. In the present work too, more often than not, $\boldsymbol{H}$. vaginalis was isolated together with a mixed flora. The frequently observed pure cultures of $H$. vaginalis reported by Gardner \& Dukes (1955) were noted in only three instances out of 122 patients in the present work.

This investigation was supported by a research grant, AI-1530, from the National Institute of Allergy and Infectious Diseases, NIH, U.S. Public Health Service.

Clinical co-operation from L. A. Gray and L. O. Giesel, Jr. (Louisville, Kentucky) and from H. L. Gardner (Houston, Texas) is gratefully acknowledged. The authors are also grateful to Dr C.D. Dukes (Baylor University, College of Medicine, Houston, Texas) who very generously made available his laboratory for studies carried out in Houston.

\section{REFERENCES}

Amies, C. R. \& Jones, S. A. (1957). A description of Haemophilus vaginalis and its Lforms. Canad. J. Microbiol. 3, 579.

Brewer, J. I., Halpern, B. \& Thomas, G. (1957). Haemophilus vaginalis vaginitis. Amer. J. Obstet. Gynaec. 74, 834.

de la Fuente, F., Rico, L. R. \& Soria, F. (1959). Hemofilasis urogenital afecion venerea. Rev. Esp. Obstet. Ginec. 18, 252.

Dukes, C. D. \& Gardner, H. L. (1961). Identification of Haemophilus vaginalis. J. Bact. 81, 277.

EDmunds, P. N. (1959). Haemophilus vaginalis; its association with puerperal pyrexia and leucorrhea. J. Obstet. Gynaec. Brit. Emp. 66, 917.

EDmunds, P. N. (1960). Haemophilus vaginalis; morphology, cultural character and viability. J. Path. Bact. 79, 273.

Gardner, H. L. \& Dukes, C. D. (1954). New etiologic agent in nonspecific vaginitis. Science, 120, 853 . 
Gardner, H. L. \& Dukes, C. D. (1955). Haemophilus vaginalis vaginitis: A newly defined specific infection, previously classified as non-specific vaginitis. Amer. J. Obstet. Gynec. 69, 962.

Gardner, H. L., Dampeer, T. K. \& Dukes, C. D. (1957). The prevalence of vaginitis. A study in incidence. Amer. J. Obstet. Gynec. 73, 1080.

Heltar, A. (1959). Haemophilus vaginalis and non-specific vaginitis. Ann. N.Y. Aca'p Sci. 83, 290.

Kummel, J. \& Ritzerfeld, W. (1961). Untersuchungen uber die Klimische Bedeutung von Haemophilus vaginalis. Geburtsh. $u$. Frauenheilk. 21, 249.

LAPAge, S. P. (1961). Haemophilus vaginalis and its role in vaginitis. Acta path. microbiol. scand. $52,34$.

Lxopold, S. (1953). Heretofore undescribed organism isolated from the genito-urinary system. U.S. Forces med. J. 4, 263.

ReDmond, D. L. \& Kotcher, E. (1963). Cultural and serological studies in Haemophilus vaginalis. J. gen. Microbiol. 33, 79.

Ritzerfeld, W. \& KummeL, J. (1960). Untersuchungen zur bakteriologischen diagnostik von Haemophilus vaginalis. Zbl. Bakt. (1. Abt. Orig.) 180, 334.

Wurch, T. \& Lưt, A. (1955). Étude du contenus vaginal dans 500 cas de leucorrhoes; cytologie, microbiologie. Rev. franç. Gynéc. 50, 289. 